\title{
Studi Pemodelan Numerik Oseanografi untuk Mendukung Perencanaan Manajemen Wilayah Pesisir Terpadu di Taman Nasional Komodo
}

\author{
Titri Yan Rizki \\ ASR INDONESIA \\ E-mail: titriyr@gmail.com
}

\begin{abstract}
Abstrak
Taman Nasional Komodo (TNK), sebuah situs pariwisata internasional, telah menghasilkan rencana induk pengelolaan pesisir terpadu (KNP, 2000). Untuk meminimalkan kesenjangan dengan daerah penyangga, diperlukan suatu rencana pengelolaan pesisir terpadu untuk daerah sekitar TNK, seperti Kabupaten Bima dan Kabupaten Manggarai Barat yang memiliki potensi perikanan, keanekaragaman hayati, energi arus laut, dan juga pariwisata. Kurangnya penelitian di lokasi ini menyebabkan kurangnya pemahaman kondisi oseanografi di sekitar area TNK. Pemodelan numerik oseanografi telah disimulasikan dalam dua dimensi untuk parameter hidrodinamika seperti arus laut dan elevasi permukaan laut dengan mempertimbangkan pasang surut dan kondisi angin. Hasil simulasi ini menunjukkan bahwa ada beberapa lokasi di sekitar TNK yang berpotensi menghasilkan energi arus laut dengan kecepatan mencapai 3,5 m/s di musim timur dan $3,7 \mathrm{~m} / \mathrm{s}$ di musim barat. Selain itu, distribusi larva ikan telah disimulasikan sesuai dengan potensi perikanan di daerah, seperti kerapu, kakap, bawal, dan ekor kuning (Kabupaten Manggarai Barat, 2007). Pemodelan tersebut diharapkan dapat membantu pemerintah daerah dalam menentukan kebijakan untuk mendukung rencana pengelolaan pesisir terpadu dengan memberikan informasi kondisi hidrodinamika musiman untuk pemetaan potensi energi arus laut, gerakan ikan dan larva ikan untuk peningkatan perikanan, dan zonasi untuk konservasi keanekaragaman hayati.
\end{abstract}

Kata Kunci: Manajemen pesisir terpadu, Model numerik, Arus, Pasang surut, Perikanan.

\section{PENDAhUluan}

Taman Nasional Komodo (TNK) merupakan sebuah daerah pariwisata internasional dan Situs Warisan Dunia UNESCO yang terletak di antara Pulau Sumbawa dan Pulau Flores, dan juga di antara Laut Flores dan Selat Sumba. National Park's Authority telah menyusun dokumen 25 Year Master Plan for Management yang didukung oleh The Nature Conservancy, Universitas Gajah Mada, dan Pemerintah Kabupaten Manggarai (KNP dkk, 2000) yang meliputi rencana pengelolaan pesisir dari tiga pulau utama TNK (Komodo, Rinca, dan Padar). Namun, pada dokumen tersebut tidak terdapat rencana pengelolaan pesisir untuk daerah di sekitar TNK, seperti Bima dan Kabupaten Manggarai, meskipun daerah tersebut berada di perairan yang sama, dan memiliki kondisi ekosistem dan ekologi yang sama. Gambar 1 di bawah ini menunjukkan bahwa batas yang diusulkan dan zona penyangga pada dokumen tersebut tidak disusun berdasarkan kondisi oseanografi, karena tidak semua perairan dan daratan di sekitar TNK termasuk di dalamnya. 


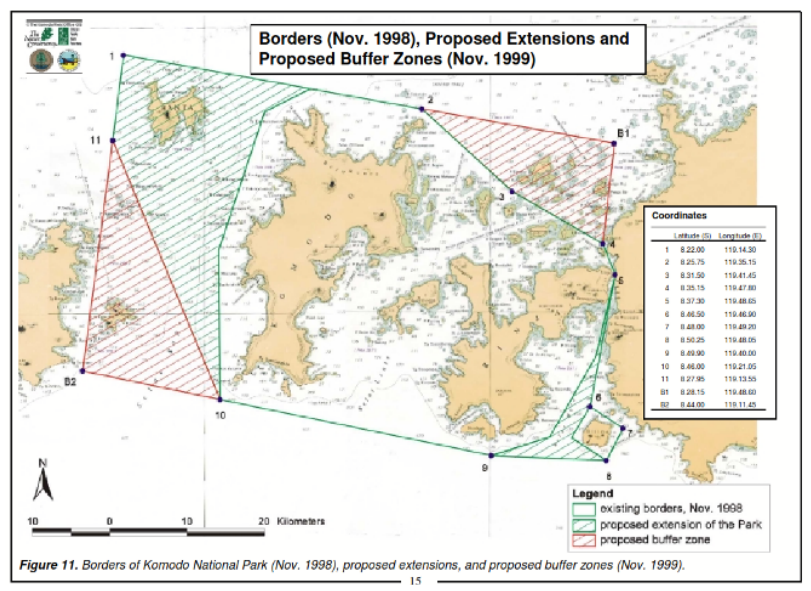

Gambar 1. Batas daerah Taman Nasional Komodo (Sumber: KNP et al., 2000)

Kondisi hidrodinamika TNK sangat kompleks karena dipengaruhi oleh pasang surut, gelombang, faktor angin, densitas, topografi serta intervensi dari aktivitas manusia. Namun, belum terdapat literatur tentang dinamika laut dan perairan pesisir sekitar wilayah tersebut. Oleh karena itu, studi yang sistematis perlu dilakukan untuk mengetahui peran laut dan sirkulasi air daerah ini untuk pengelolaan keanekaragaman hayati dan sumber daya pesisir yang berkelanjutan. Berikut adalah beberapa data oseanografi di sekitar TNK dan Labuan Bajo, baik data primer maupun sekunder, yang telah dipublikasi.

\begin{tabular}{|l|l|}
\hline Data & Sumber \\
\hline Data Meteorologi & $\begin{array}{l}\text { - Komodo Airport Meteorological } \\
\text { Station Labuan Bajo, NTT } \\
\text { - M. Salahudin Meteorological } \\
\text { Station Bima, NTB }\end{array}$ \\
\hline $\begin{array}{l}\text { Data Temperatur and } \\
\text { salinitas pada penelitian } \\
\text { tahun 1940 }\end{array}$ & World Ocean Database2009 NOAA \\
\hline $\begin{array}{l}\text { data bathymetri global } \\
\text { resolusi 925 km }\end{array}$ & GEBCO \\
\hline $\begin{array}{l}\text { Peta Bathymetri Nusa } \\
\text { Tenggara skala 1: 200,000 }\end{array}$ & Dishidros TNI-AL \\
\hline $\begin{array}{l}\text { Peramalan pasang surut } \\
\text { Bima (118.7BT and } 8.4^{0} \text { LS) }\end{array}$ & Dishidros TNI-AL \\
\hline $\begin{array}{l}\text { Climatology reanalysis data } \\
\text { Labuan Bajo (120 } \\
\text { 8,57 and }\end{array}$ & $\begin{array}{l}\text { National Centers for Environmental } \\
\text { Prediction (NCEP) NOAA }\end{array}$ \\
\hline Data kuantitatif perikanan & http://manggaraibaratkab.bps.go.id \\
\hline $\begin{array}{l}\text { PPDPI Jawa, Bali and Nusa } \\
\text { Tenggara }\end{array}$ & $\begin{array}{l}\text { BPOL- Ministry of Marine Affair and } \\
\text { Fisheries }\end{array}$ \\
\hline $\begin{array}{l}\text { Kondisi umum oseanografi } \\
\text { Flores }\end{array}$ & Naga Report by Klaus Wyrtki (1961) \\
\hline
\end{tabular}

Meskipun tampaknya terdapat banyak data seperti pada Tabel 1 , tetapi data-data tersebut tidak mewakili kondisi oseanografi spesifik di lokasi penelitian. Berbagai penelitian yang dilakukan oleh pusat penelitian di bawah Kementerian Kelautan dan Perikanan tidak melakukan pengambilan data di lokasi tersebut. Dokumen 25 Year Master Plan for Management juga menyebutkan kurangnya studi oseanografi yang dilakukan di sekitar TNK. Keberadaan 
pelampung survey di beberapa titik di sekitar TNK tidak disertai dengan peralatan perekaman data oseanografi. Karena berbagai alasan di atas, diperlukan survei lapangan yang menyeluruh untuk menentukan kondisi oseanografi di daerah tersebut.

Studi ini telah memprakarsai perencanaan pengelolaan wilayah pesisir terpadu dengan pemerintah daerah di wilayah ini yang mencakup seluruh wilayah antara wilayah timur Pulau Sumbawa dan Pulau Flores Barat. Pemodelan oseanografi yang dilakukan diharapkan dapat membantu pemerintah daerah dalam menentukan kebijakan untuk mendukung rencana pengelolaan pesisir terpadu dengan memberikan informasi kondisi hidrodinamika untuk memetakan potensi energi arus laut, gerakan ikan dan larva ikan untuk peningkatan perikanan, dan zonasi lokal untuk konservasi keanekaragaman hayati.

\section{METODOLOGI}

\subsection{Model Hidrodinamika dan Model Sebaran Partikel}

Pemodelan numerik oseanografi telah disimulasikan dalam mode 2-dimensi (2D) perata-rataan terhadap kedalaman. Parameter hasil model hidrodinamika yang didapat yaitu arus laut dan elevasi permukaan laut dengan mempertimbangkan kondisi pasang surut dan angin untuk simulasi musim timur (Agustus) dan musim barat (Januari).

Persamaan gerak horisontal yang digunakan:

$$
\begin{aligned}
& \frac{\partial u}{\partial t}+u \frac{\partial u}{\partial x}+v \frac{\partial u}{\partial y}+w \frac{\partial u}{\partial z}-f v=-g \frac{\partial \zeta}{\partial x}-\frac{1}{\rho} \frac{\partial P}{\partial x}+A_{H}\left(\frac{\partial^{2} u}{\partial x}+\frac{\partial^{2} u}{\partial y}\right)+\frac{\partial}{\partial z}\left(N_{z} \frac{\partial u}{\partial z}\right) \\
& \frac{\partial}{\partial}+u \frac{\partial}{\partial x}+v \frac{\partial}{\partial y}+w \frac{\partial v}{\partial z}+f u=-g \frac{\partial \zeta}{\partial y}-\frac{1}{\rho} \frac{\partial P}{\partial y}+A_{H}\left(\frac{\hat{\partial}^{2} v}{\partial x}+\frac{\hat{\partial}^{2} v}{\partial y}\right)+\frac{\partial}{\partial z}\left(N_{z} \frac{\partial v}{\partial z}\right) \\
& w=-\frac{\partial}{\partial x} \int_{-h}^{z} u d z-\frac{\partial}{\partial y} \int_{-h}^{z} v d z
\end{aligned}
$$

$t$ adalah waktu, $u, v$ adalah kecepatan horisontal di $x, y$ arah masing-masing, $w$ kecepatan vertikal (positif ke atas), $h$ kedalaman, $g$ percepatan gravitasi, $\varsigma$ datum horisontal di atas permukaan laut, $f$ parameter Coriolis , $P$ tekanan, $A H$ koefisien viskositas eddy horisontal, dan $\mathrm{Nz}$ koefisien viskositas eddy vertikal dan $\rho$ adalah densitas yang bervariasi dengan kedalaman.

Dengan asumsi bahwa percepatan vertikal diabaikan, persamaan hidrostatik untuk tekanan di kedalaman $z$ adalah:

$$
P=P_{a t m}+g \int_{z}^{\varsigma} \rho d z
$$

dengan $P_{a t m}$ adalah tekanan atmosfer.

Syarat batas di permukaan $z=\varsigma$ adalah:

$$
\rho N_{z} \frac{\partial u}{\partial z}=\tau_{x}^{s} \quad \rho N_{z} \frac{\partial v}{\partial z}=\tau_{y}^{s} \quad \frac{\partial \varsigma}{\partial t}+u \frac{\partial \varsigma}{\partial x}+v \frac{\partial \varsigma}{\partial y}=w^{s}
$$


dimana $\tau_{x}^{S}, \tau_{y}^{S}$, a alah komponen stress angin, $w^{s}$ adalah kecepatan vertikal di permukaan

$$
\tau_{x}^{s}=\rho_{a} \gamma|\mathrm{W}| \frac{\mathrm{W}_{x}}{\rho} \quad \tau_{y}^{s}=\rho_{a} \gamma|\mathrm{W}| \frac{\mathrm{W}_{y}}{\rho}
$$

$\rho$ adalah densitas air, $W$ kecepatan angin di $10 \mathrm{~m}$ di atas permukaan laut, sementara $W x$ dan $W y$ adalah komponen $x$ dan $y, \gamma$ adalah koefisien hambatan angin, $\rho$ a densitas udara. Koefisien hambatan angin berasal dari karya $\mathrm{Wu}(1982)$ dengan koefisien drag $\gamma$ yaitu

$$
\gamma=\left(0.8+0.065 \mathrm{~W}_{\mathrm{s}}\right) \times 10^{-3}
$$

Dengan asumsi kemiringan dasar laut kecil, $z=h$

$$
N_{z} \frac{\partial u}{\partial z}=\tau_{x}^{h} \quad N_{z} \frac{\partial v}{\partial z}=\tau_{y}^{h}
$$

dimana $\tau_{x}^{h}, \tau_{y}^{h}$ adalah komponen gesekan dasar

$$
\begin{aligned}
& \tau_{x}^{h}=\mathrm{g} u_{\mathrm{h}}\left(u_{h}^{2}+v_{\mathrm{h}}^{2}\right)^{1 / 2} / C^{2} \\
& \tau_{y}^{h}=\mathrm{g} v_{\mathrm{h}}\left(u_{h}^{2}+v_{\mathrm{h}}^{2}\right)^{1 / 2} / C^{2}
\end{aligned}
$$

dengan $u_{h}, v_{h}$ adalah kecepatan arus di dasar dan $C$ adalah koefisien Chezy.

Selain model hidrodinamika, distribusi penyebaran partikel konservatif telah disimulasikan dan dikembangkan menjadi model distribusi larva ikan untuk spesies tertentu sesuai dengan potensi perikanan di daerah tersebut.

Persamaan pada model Lagrangian yang digunakan yaitu:

$$
\begin{aligned}
\frac{\partial C}{\partial t}=\frac{\partial}{\partial x}\left[E_{x} \frac{\partial C}{\partial x}-U C\right] & +\frac{\partial}{\partial y}\left[E_{y} \frac{\partial C}{\partial y}-V C\right] \\
& +\frac{\partial}{\partial z}\left[E_{z} \frac{\partial C}{\partial z}+w_{z} C-W C\right]-k C+S_{s}
\end{aligned}
$$

\subsection{Data Batimetri}

Jarak grid model horizontal sebesar $500 \mathrm{~m}$ dengan menggabungkan data batimetri dari General Bathymetric Chart of the Oceans (GEBCO) dan peta navigasi Dishidros TNI-AL 2012 seperti dapat dilihat pada Gambar 2 (bawah) di bawah ini. Grid model horizontal menggunakan metode kartesian. Kedalaman air bervariasi dari kurang dari 1 meter hingga ratusan meter di dekat daratan dan bertambah menjadi ribuan meter ke arah utara. Sementara kedalaman air meningkat ke selatan sampai 2.000 meter dan kemudian menurun menuju Pulau Sumba. Kondisi batimetri tersebut akan mempengaruhi dinamika sirkulasi air. 


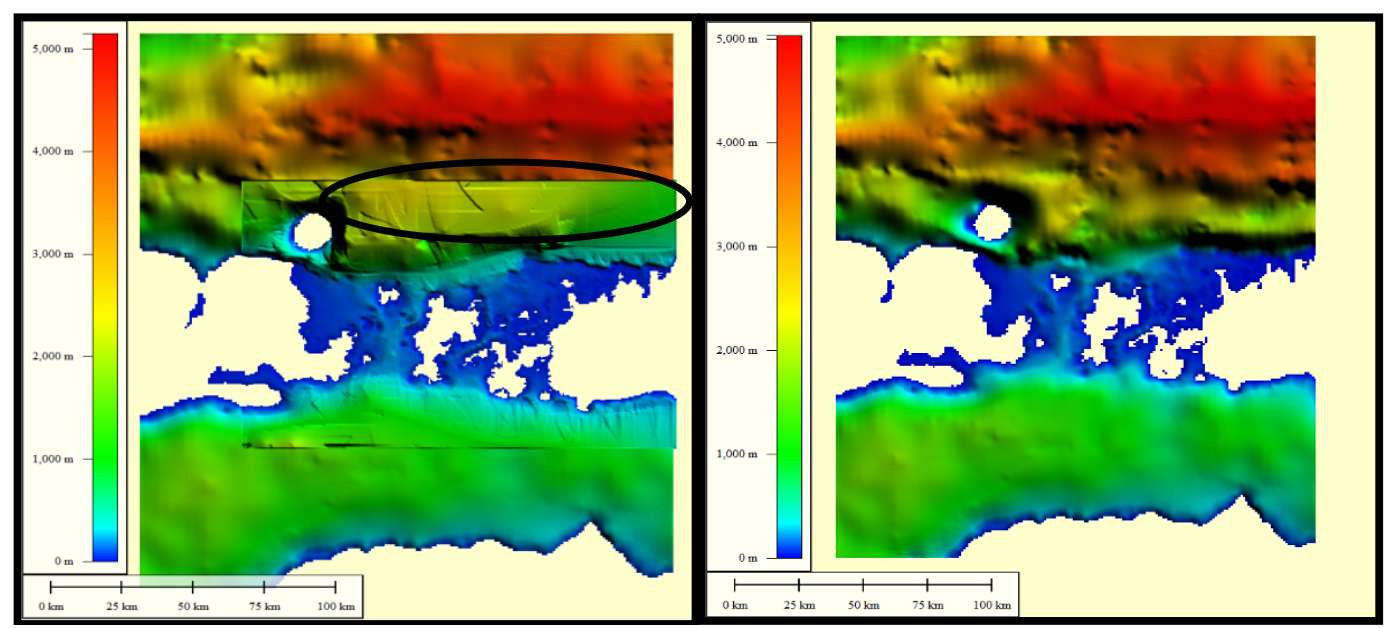

Gambar 2. Data batimetri untuk input model sebelum diproses (kanan) dan setelah diproses (kiri)

Kondisi batimetri yang disebutkan di atas berasal dari perkiraan data aktual karena terdapat perbedaan nilai kedalaman yang signifikan (perbedaan mencapai $3000 \mathrm{~m}$ ) antara data global dan data Dishidros seperti yang ditunjukkan oleh lingkaran hitam pada Gambar 2 (atas). Untuk mengatasi masalah ini, survei batimetri harus dilakukan sehingga hasil model akan lebih akurat.

\subsection{Nilai Awal dan Syarat Batas Model}

Data stasioner profil perariran horizontal digunakan sebagai nilai awal pada model. Terdapat 6 daerah terbuka pada daerah model seperti tampak pada Gambar 2. Pada batas terbuka, diberikan data elevasi pasang surut yang didapatkan dari Tide Model Driver (TMD). Untuk mendapatkan hasil model yang lebih sesuai dengan kondisi sesungguhnya, perlu dilakukan pengamatan data lapangan minimal pada 2 titik di daerah terbuka model.

Data input angin komponen $u$ dan $v$ didapatkan dari National Centres for Environmental Prediction (NCEP) pada koordinat $120^{\circ} \mathrm{BT}$ and $8.571^{\circ} \mathrm{LS}$ (Labuan Bajo) dengan interval data 6 jam seperti terlihat pada Gambar 3.Data tersebut merupakan data sekunder dari hasil metode reanalisis, sehingga perlu dilakukan validasi dengan data lapangan. Pada musim barat angin dominan bergerak menuju ke arah tenggara dan sebaliknya pada musim timur angin dominan bergerak menuju ke arah barat laut.
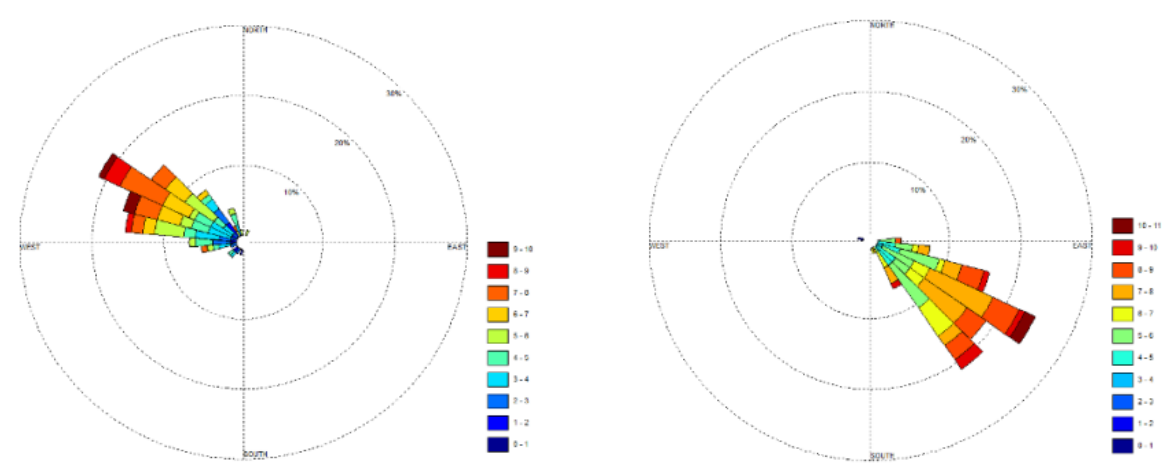

Gambar 3. Wind rose musim barat (kanan) dan musim timur (kiri) 


\section{HASIL DAN PEMBAHASAN}

\subsection{Validasi Model}

Nilai Elevasi dari hasil model diverifikasi dengan data elavasi dari Daftar Pasang Surut Tahun 2012 oleh Dishidros TNI-AL di stasiun Bima pada koordinat $118.7^{\circ} \mathrm{BT}$ and $8.4^{\circ}$ LS pada $1-15$ Januari 2012. Perbandingan antara hasil model dengan data peramalan Dishidros menunjukkan nilai yang cukup baik, seperti ditunjukkan pada Gambar 4, yaitu fasa yang sama dengan perbedaan amplitudo mencapai $0,3 \mathrm{~m}$ saat pasang maksimum dan surut minimum ketika pasut purnama dan nilai amplitudo yang sama ketika pasut perbani. Perbedaan ini dapat disebabkan input model yang memiliki 8 komponen pasut sedangkan peramalan Dishidros hanya terdiri atas 5 komponen pasut.

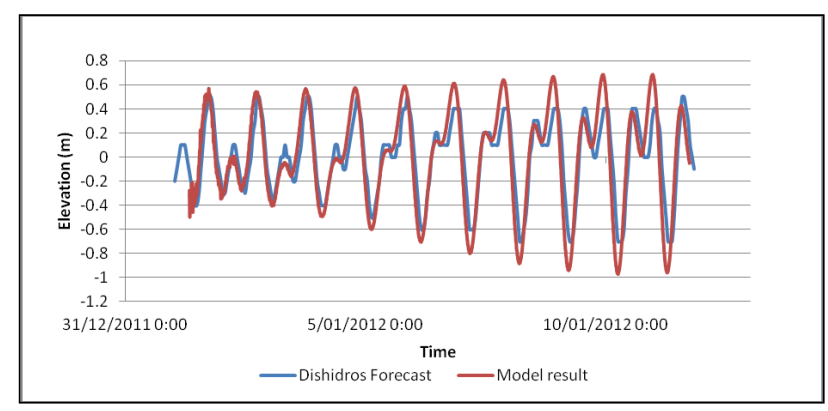

Gambar 4. Perbandingan nilai elevasi hasil Model dengan data peramalan Dishidros di Bima.

\subsection{Hasil Model Hidrodinamika}

Model hidrodinamika menghasilkan gambaran sirkulasi air (arus dan permukaan laut). Pada kondisi pasang, arus bergerak ke utara, sementara pada kondisi surut bergerak ke selatan. Umumnya, besarnya arus di laut Flores kurang dari 0,2 m/ s dan meningkat ke arah Selat Sape dan Selat Linta mencapai lebih dari $3 \mathrm{~m} / \mathrm{s}$ dan berkurang ke arah selatan memasuki Selat Sumba menjadi kurang dari $0,2 \mathrm{~m} / \mathrm{s}$.

Kecepatan arus pada musim barat umumnya lebih besar daripada musim timur yang dapat disebabkan input angin yang digunakan pada model memiliki nilai kecepatan rata-rata yang lebih besar di musim barat.

Kecepatan arus rata-rata saat pasang di Selat Sape dan Selat Linta $0,2 \mathrm{~m} / \mathrm{s}$ lebih besar dari kecepatan arus rata-rata saat surut karena adanya perbedaan tinggi permukaan laut antara Laut Flores di sisi utara dan Selat Sumba di sisi selatan, mencapai sekitar 1 meter baik saat pasang maupun saat surut

Pola sirkulasi horisontal saat pasang dan surut di musim barat ditunjukkan pada Gambar 5 dan di musim timur pada Gambar 6, sebagai berikut: 


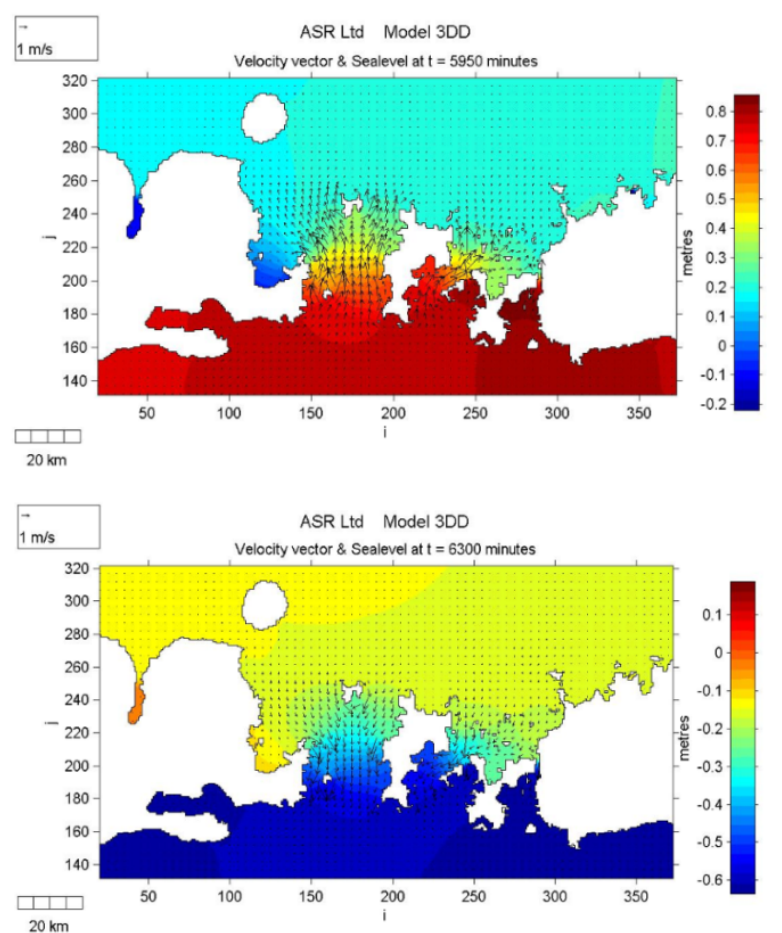

Gambar 5. Vektor arus dan nilai elavasi saat pasang (atas) dan saat surut (bawah) di musim barat

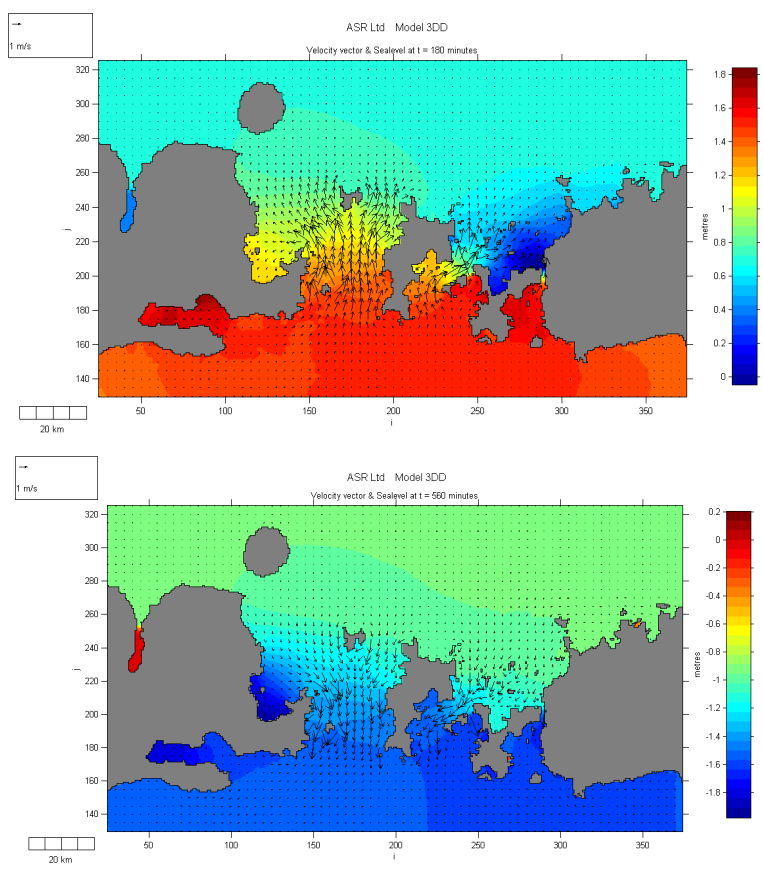

Gambar 6. Vektor arus dan nilai elavasi saat pasang (atas) dan saat surut (bawah) di musim timur

Hasil simulasi ini juga menunjukkan bahwa terdapat beberapa lokasi di sekitar TNK yang berpotensi menghasilkan energi non-terbarukan oleh arus laut dengan kecepatan mencapai 3,5 $\mathrm{m} / \mathrm{s}$ di musim timur dan 3,7 m/s di musim barat, yaitu di dalam Selat Sape dan Selat Linta.

Model perlu dikembangkan dengan teknik nested-model untuk mendapatkan hasil dengan resolusi lebih kecil dan mampu menggambarkan fenomena yang lebih detail seperti pusaran 
air/eddies yang dapat terjadi karena kompleksnya batimetri di pulau-pulau kecil di sekitar TNK. Selain itu, model juga perlu dikembangkan menjadi 3 dimensi karena kedalaman yang sangat bervariasi terutama di sekitar Pulau Komodo akan menghasilkan nilai kecepatan yang bervariasi terhadap kedalaman.

\subsection{Hasil Model Sebaran Larva ikan}

Berdasarkan data Pemerintah Kabupaten Manggarai Barat, potensi perikanan yang sangat besar, diantaranya kerapu, kakap, dan bawal. Beberapa skenario model telah dikembangkan untuk mengoptimalkan pemanfaatan perikanan. Skenario pertama yaitu ikan kerapu dan kakap, yang merupakan ikan karang dengan kemampuan berenang dengan kecepatan 5-47 cm / s, tergantung pada ukuran tubuh. Skenario kedua yaitu ikan bawal, yang bergerak dengan kecepatan mencapai $30-40 \mathrm{~cm} / \mathrm{s}$ tergantung pada ukuran tubuh, dan sangat dipengaruhi oleh suhu, sehingga ketika malam mereka berada di permukaan $(<10 \mathrm{~m})$ dan pada siang hari bergerak lebih dalam $(20-30 \mathrm{~m})$ (Leis, et.al., 2007).
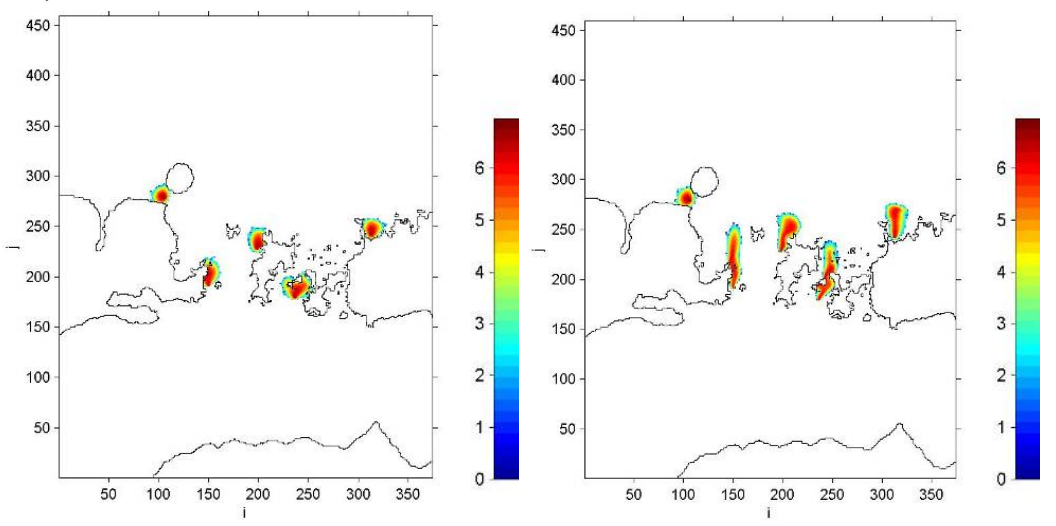

Gambar 8. Sebaran larva ikan kerapu dan kakap pada titik tertentu di musim barat (kanan) dan musim timur (kiri)
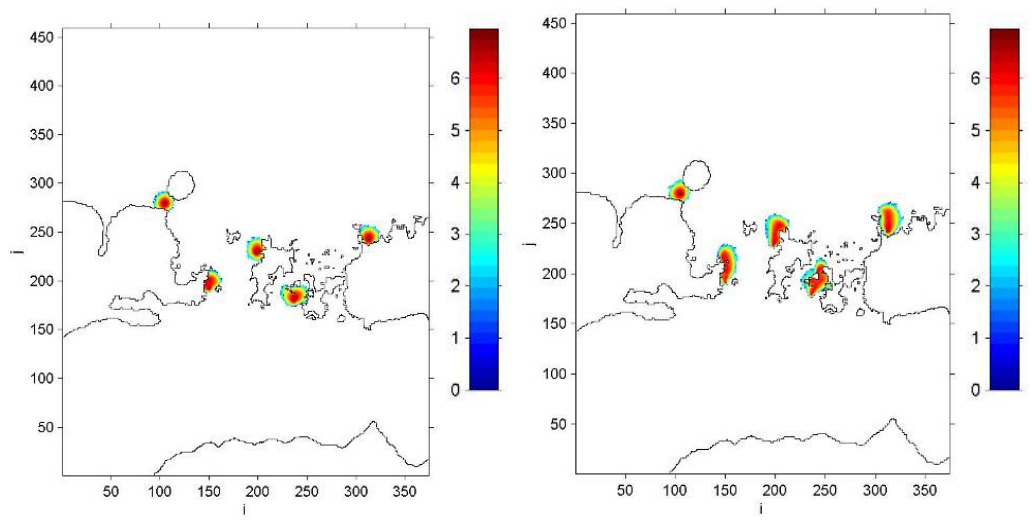

Gambar 9. Sebaran larva ikan bawal kakap pada titik tertentu di musim barat (kanan) dan musim timur (kiri)

Hasil model menunjukkan bahwa sebaran larva umumnya bergerak ke utara karena kecepatan arus rata-rata saat pasang yang lebih besar dibandingkan seperti telah dijelaskan sebelumnya. Pada Gambar 8 dan Gambar 9, sirkulasi air secara signifikan dipengaruhi oleh angin musiman. Larva ikan berenang lebih jauh ke arah utara pada musim timur di bulan Agustus karena arah 
angin yang bergerak ke arah utara-barat laut. Ikan kerapu dan kakap berenang lebih cepat daripada ikan bawal, sehingga skenario pertama menghasilkan area persebaran larva yang lebih luas dari skenario kedua.

Model sebaran larva ini diperoleh berdasarkan data yang terbatas tentang perikanan potensial di TNK. Untuk studi lebih lanjut, model harus mempertimbangkan kondisi fisik seperti suhu, salinitas, dan kekeruhan perairan, serta parameter biologis yang mempengaruhi seperti nutrien (nitrat, fosfat) dan fitoplankton. Selain itu, diperlukan juga informasi dasar tentang potensi perikanan sekitar TNK misalnya: jenis, perilaku fisik, dan wilayah habitat ikan. Penelitian lebih lanjut perlu diperoleh untuk menghasilkan pemetaan zonasi yang disusun dari hasil-hasil pemodelan sebagai dasar untuk pengelolaan yang berkelanjutan dan konservasi sumber daya pesisir dan laut di wilayah ini.

\section{KESIMPULAN}

Kondisi hidrodinamika di perairan di sekitar TNK sangat kompleks karena banyak faktor yang berpengaruh seperti faktor fisis laut dan faktor meteorologis serta adanya intervensi dari aktivitas manusia. Untuk mengelola sumber daya laut secara berkelanjutan diperlukan pemahaman yang menyeluruh terhadap kondisi tersebut melalui penelitian-penelitian diantaranya dapat melalui pemodelan oseanografi serta pengumpulan data lapangan.

Hasil penelitian menunjukkan bahwa perairan secara umum dipengaruhi oleh kondisi pasang surut dan angin dengan nilai kecepatan arus yang lebih besar saat musim barat dibandingkan saat musim timur, dengan kecepatan maksimum mencapai $3,7 \mathrm{~m} / \mathrm{s}$. Nilai kecepatan arus yang dihasilkan dijadikan dasar untuk mendapatkan pola musiman sebaran larva ikan.

Penelitian ini diperoleh dengan menggunakan data yang terbatas untuk wilayah TNK sehingga input model hidrodinamika dan model sebaran larva ikan tidak didasarkan pada data observasi. Model ini juga tidak divalidasi menggunakan data lapangan karena tidak ada pengamatan pasang surut yang pernah diselenggarakan di daerah ini. Survei oseanografi terpadu perlu dilakukan untuk menentukan kondisi fisik di perairan Manggarai Barat dan juga untuk memvalidasi hasil model.

\section{DAFTAR PUSTAKA}

[1] Black, K.P. dan Hatton. Two and Three-dimensional numerical Hydrodynamic and Dispersal models of an Exposed coastal site. In South-eastern Ocean Outfall Study: Volume 2. Victorian Institute of Marine Sciences: Appendices -Page. A.33-A.38. 1992.

[2] Black, K.P. The Hydrodynamic Model 3DD and Support Software. Occasional report No.19. 53 pp. 1996.

[3] Black K.P Lagrangian Dispersal and Sediment Transport Model an Support Software. Occasional report no. 20. Department of Earth Sciences. New Zealand: University of Waikato and NIWA, Hamilton. 1996.

[4] Black, K.P., Healy T.R., de Lange W.P, Gorman R, Dolphin T. Field Measurements in Coastal Marine Science. Department of earth Sciences. New Zealand: University of Waikato. Private Bag 3105. Hamilton. 1996.

[5] Black, K.P. dan de Lange W.P. Lectures Notes: Numerical Modelling of Physical Marine Processes. Department of earth Sciences. New Zealand: University of Waikato. Private Bag 3105. Hamilton. 1995.

[6] Bowden K.F., Krauel D.P. dan Lewis. R.E. Some Features of Turbulent Diffusion from A Continuos source at Sea. Annual Review of Fluid Mechanics. 1983. 
[7] Chu, W.S. Remaining Problems in the Practical Application of Numerical Models to Coastal Waters in Application in Coastal Modelling. Lakhan, V.C dan Trenhaile (eds). Elsevier Oceanography Series. 1989; $355-369$.

[8] Chu, W.S. and Yeh, W.W.G. Calibration of a Two-dimensional Hydrodynamics Model. Coastal Engineering. 1985; 293-308.

[9] Csanady G.T. Turbulent Diffusion in the Environment., D. Reidel Publ.Co. 1973; p.249.

[10] Dishidros TNI-AL. Daftar Pasang Surut Tahun 2012. Dishidros TNI-AL. 2012.

[11] Falconer, R.A. Flow and Water Quality Modelling in Coastal and Inland Water. Journal of Hydraulic Research. 1992; 30: 437-452.

[12] Gordon, R.B. and Spaulding, M.L. Numerical Simulation of the tidal- and wind-driven circulation in Narragansett Bay. Jour. of. Estuarine Coastal and Shelf Science. 1987; 24(5): 611636.

[13] Komodo National Park. 25 Year Master Plan for Management, Book 1: Management Plan. Komodo National Park's Authority. 2000.

[14] Komodo National Park. 25 Year Master Plan for Management, Book 2: Data and Analysis. Komodo National Park's Authority. 2000.

[15] Komodo National Park. 25 Year Master Plan for Management, Book 3: Site Planning. Komodo National Park's Authority. 2000.

[16] Koutitas, C.G. Mathematical Model in Coastal Engineering. Pentech Press. 1988; p.156.

[17] Leis, Jeffrey M. Behaviour as Input for Modelling Dispersal of Fish Larvae: Behaviour, Biogeography, Hydrodinamics, Ontogeny, Physiology, and Phylogeny Meet Hydrography. Marine Ecology Progress Series. 2007; 347: 185-193.

[18] Leis, Jeffrey M., Amanda C. Hay ${ }^{1}$, Matthew M. Lockett ${ }^{1}$, Jeng-Ping Chen ${ }^{2}$, Lee-Shing Fang. Ontogeny of swimming speed in larvae of pelagic-spawning, tropical, marine fishes. Marine Ecology Progress Series. 2007; 349: 257-269.

[19] Lendertse, J.J. and Liu, S.K. Modelling of three-dimensional flows in Estuaries. 2nd Annual Symposium on Modelling Techniques. Waterways, Harbour and Coastal Engineering (ASCE). $1975 ; 625-642$

[20] Liu, S.K. and Lendertse, J.J. Multidimensional Numerical Modelling of Estuaries and Coastal Seas. Advances in Hydroscience. 1978; 11: 95-160.

[21] Meyer, Trevor, Sudaryanto, Peter M., dan Jos P. Sustainable, profitable and socially responsible-building a'triple bottom line'grouper and snapper culture industry in Komodo. Aquaculture Asia. 2004; 9(4): 34-36.

[22] Pearcy, W.G., Fisher, J.P. dan Yoklavich, M.M. Biology of the Pacific pomfret (Brama japonica) in the North Pacific Ocean. Canadian Journal of Fisheries and Aquatic Sciences. 1993;50(12):2608-2625.

[23] Ramming, H.G. and Kowalik. Numerical Modelling of Marine Hydrodynamics. Applications to Dynamical Physical Processes. Elseviers Oceanography Series 26. 1980.

[24] Sudaryanto, Trevor M., and Peter M. Natural Spawning of Three Species of Grouper in Floating Cages at a Pilot Broodstock Facility at Komodo, Flores, Indonesia. SPC Live Reef Fish Information Bulletin \#12, February. 2004.

[25] WWF Indonesia. Perikanan Kerapu dan Kakap, Panduan Penangkapan dan Penanganan. Seri Panduan Perikanan Skala Kecil versi 1, Oktober. 2011.

[26] D. Gorinevsky, S. Boyd, G. Stein, Optimization-based tuning of low-bandwidth control in spatially distributed systems, American Control Conference. 2003; 3: 2658-2663. 